\title{
PRELIMINARY ASSESSMENT OF THE GEOTHERMAL POTENTIAL OF THE NORTHERN HASSAYAMPA PLAIN, MARICOPA COUNTY, ARIZONA
}

\author{
by \\ Claudia Stone \\ Arizona Geological Survey \\ Open-File Report 79-17
}

Arizona Geological Survey

416 W. Congress, Suite \#100, Tucson, Arizona 85701

This report is preliminary and has not been edited

or reviewed for conformity with Arizona Geological Survey standards 

INTRODUCTION

A preliminary assessment of the geothermal potential of the western half of the northern Hassayampa Plain has been made. A single shallow well with a measured temperature of $51{ }^{\circ} \mathrm{C}$ initially called attention to the area. Field investigations were carried out between January and July, 1979. The field program consisted of (1) temperature logging of available water wells and mineral test holes, (2) collecting soil samples for mercury analysis, (3) taking water samples for major cation and anion analyses, and (4) conducting reconnaissance geologic mapping along the northeast side of the Belmont Mountains. Parts of this report are taken from published maps and reports and from unpublished field investigations conducted in 1972-73 by Fugro, Inc., Long Beach, California, and used here with their permission.

\section{GENERAL SETTING}

The northern Hassayampa Plain is bounded by the Hieroglyphic Mountains on the northeast, the Vulture Mountains on the north, and the Belmont and White Tank Mountains on the southwest and southeast sides (Fig. 1). The Hassayampa River, an intermittent stream, flows south through the center of the region and defines the approximate eastern boundary of the present area of investigation. Other boundaries of the study area are the Belmont and Vulture Mountains. 


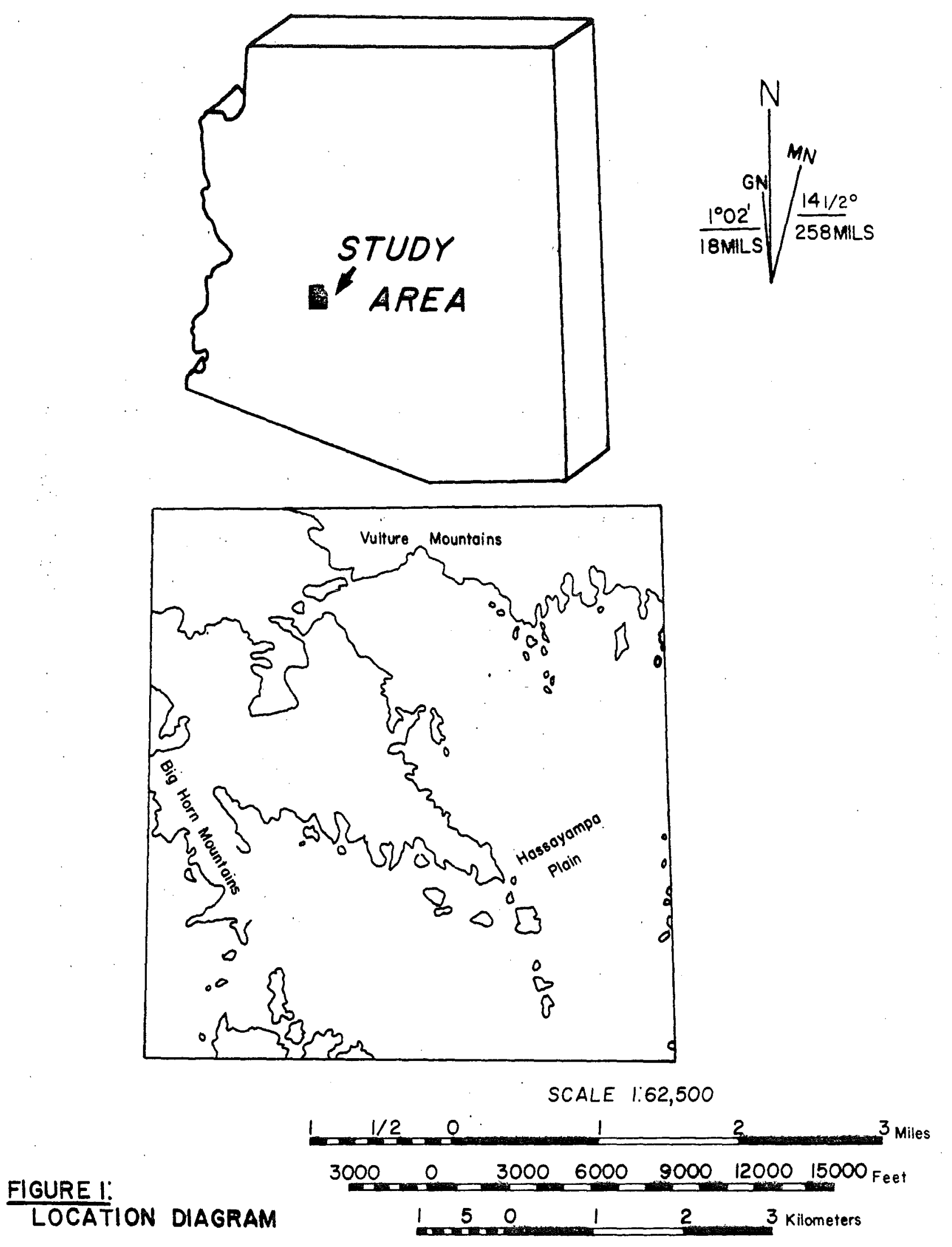

(

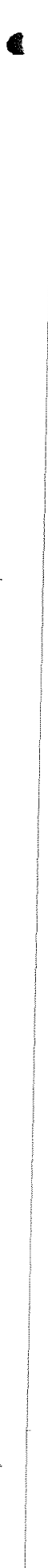

2 
Daily average temperatures at Wickenburg, slightly northeast of the Vulture Mountains, vary between $8.2^{\circ} \mathrm{C}$ $\left(46.7^{\circ} \mathrm{F}\right)$ and $30.4^{\circ} \mathrm{C}\left(86.7^{\circ} \mathrm{F}\right)$ with a mean annual temperature of about $18.4^{\circ} \mathrm{C}\left(65.1^{\circ} \mathrm{F}\right)$. Precipitation ranges from 0.15 to 2.24 inches per month; the annual normal precipitation at Wickenburg is 10.76 inches (NOAA, 1973).

HYDROLOGIC SETTING

Surface Water

Throughout the entire Hassayampa drainage area (1074 $\mathrm{km}^{2}$ ) the average annual runoff is less than 0.1 inch. Surface runoff in the study area is channelled into two major intermittent streams, Star Wash and Jackrabbit Wash, which trend south and southeastward, respectively. Star Wash enters Jackrabbit Wash east of the Belmont Mountains. Several miles further south Jackrabbit Wash enters the Hassayampa River.

\section{Ground Water}

Contours of water-level altitudes above mean sea level (Fig. 2) were drawn on the basis of available water well data, bedrock outcrops, and an unpublished gravity survey of 1 imited extent $\left(107 \mathrm{~km}^{2}\right)$ in the Indian Buttes area (Fugro, 1979). The paucity of data renders any interpretation conjectural and subject to revision as additional data are acquired. With this understanding, an attempt is made to explain the hydrologic setting of the region. 
The altitude of ground water above mean sea level decreases to the southeast, reaches a low northeast of the Belmont Mountains (Fig. 2) and then gently rises again, creating a saddle-like configuration. This undulation is likely caused by either shallowing of bedrock between the Belmont Mountains to the west and the White Tank Mountains to the east, or mounding of ground water between the two ranges. In either case, it appears that the constriction between the Belmont and White Tank Mountains creates a natural ground-water divide between the northern and southern Hassayampa areas. The shallow water-level gradients in the center of the study area, opposed to steeper gradients closer to the range fronts, indicate a highly permeable aquifer beneath the central portion of the northern Hassayampa Plain.

Depth to water below the land surface ranges from about $13 \mathrm{~m}$ in the Belmont Mountains to a reported depth of greater than $200 \mathrm{~m}$ south of the Vulture Mountains. Shallow water levels along the northeast side of the Belmont Mountains indicate that the water there is being held up by a pediment. Near the center of the plain, depth to water is about $145 \mathrm{~m}$ and it decreases to the southeast.

Recharge to the aquifer is from the contiguous mountain ranges, with the rate of recharge being. small owing to low precipitation. The intermittent nature of the Hassayampa River makes it unlikely that much recharge to the ground 
Figure 2. PROPOSED BEDROCK AND HYDROLOGIC CONDITIONS

\section{EXPLANATION}

- $\frac{435}{1645}$
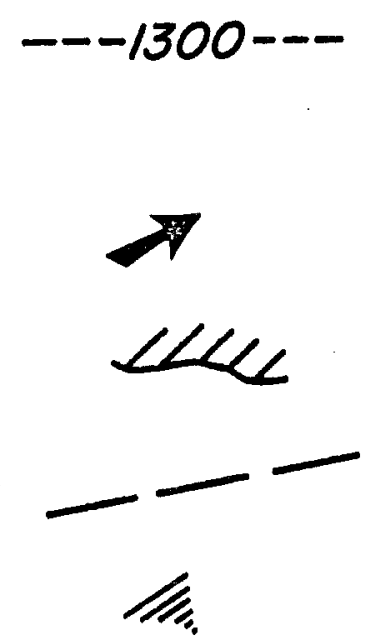

Upper number is depth to water below land surface (feet); lower number is approximate altitude of water level above mean sea level (feet).

Contour of approximate water level above mean sea level (feet). Dotted where data are insufficient. Contour interval is 100 feet.

General direction of ground water flow.

Bedrock outcrop.

Inferred faults.

Area of shallow bedrock. 


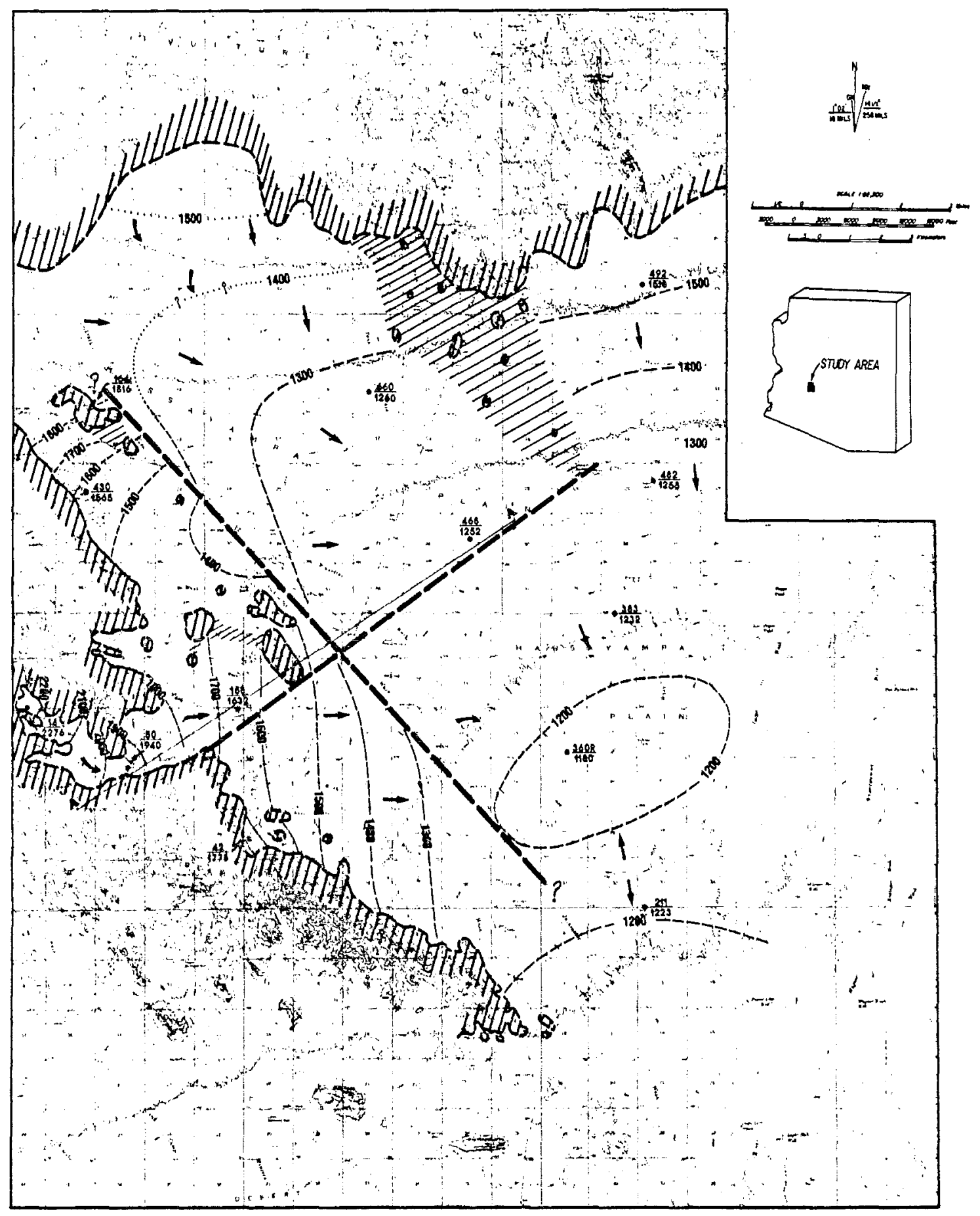

Figure 2. Proposed Bedrock and Hydrologic conditions, Northern Hassayampa Plain, Arizona. 
water system is derived from this source. Published ground water data from the study area are presently inadequate to quantitatively evaluate water balance elements such as recharge and withdrawal rates and recent water level changes. 



\section{GEOLOGY}

The Hassayampa Plain lies within the Basin and Range physiographic province of west-central Arizona. The northern Hassayampa Plain is separated from the southern plain by an eight-mile wide constriction caused by the proximity of the Belmont to the White Tank Mountains.

Vulture Mountains. Published reports on the Vulture Mountains are generally limited to early accounts of mining activity at the Vulture gold mine on the south side of the mountain. On the Geologic Map of Arizona, Wilson, Moore and Cooper (1969) show the Vulture Mountains as being composed of Precambrian granite, gneiss, and schist, and Cretaceous andesitic and rhyolitic rocks. These rocks are intruded by sills, plugs, and north-trending dikes of lateCretaceous to Tertiary age. Tertiary-Quaternary basalt flows cap much of the west end of the complex. Rehrig and Heidrick (1976) identified distinctive tectonically-oriented structures in the Vulture Mountains which they identified as Laramide and late-Tertiary in age. A comprehensive report by Rehrig, Shafiqullah, and Damon on the geochronology and geology of the Vulture Mountains is in press.

Belmont Mountains. Published references to the Belmont Mountains and the northern Hassayampa Plain are not found in the literature. Results of unpublished reconnaissance geologic mapping along the south side of the Belmont Mountains and within the northern Hassayampa Plain were made available 
for this study by Fugro, Inc., Long Beach, California. Additional geologic information is based on field investigations and air photo interpretation.

The Belmont Mountains is a small northwest-trending range that separates the northern Hassayampa Plain from the southern plain. The southeast end of the range terminates with a pile of Cretaceous (?) andesite with maximum elevation of $675.3 \mathrm{~m}$. The main section of the range comprises a barren granite ridge about $7.2 \mathrm{~km}$ long, with a maximum elevation of $956.4 \mathrm{~m}$. The age of this granite is shown as Precambrian on the state geologic map (Wilson and others, 1969). To the northwest of the granite ridge are low hills of Precambrian schist and remnants of Cretaceous andesite (Wilson and others, 1969). In the study area there are no granitic outcrops northeast of the granite ridge. However, northeast of the schist and andesite hills, numerous granitic hills protrude through the detrital sediment as far north as Jackrabbit Wash, confirming the existence of a pediment there. A geologic cross section (Fig. 3) shows details across the area.

Of the isolated outcrops examined, one hill is composed of granite intruded into schist. This granite is quite distinct from other granitic rocks examined. Specifically, the schist-intruding granite is lacking biotite which the other granites contain. Uehedral magnetite in this rock is ubiquitous. Phenocrysts of subhedral to euhedral quartz, alkali feldspar, and plagioclase are abundant. The 


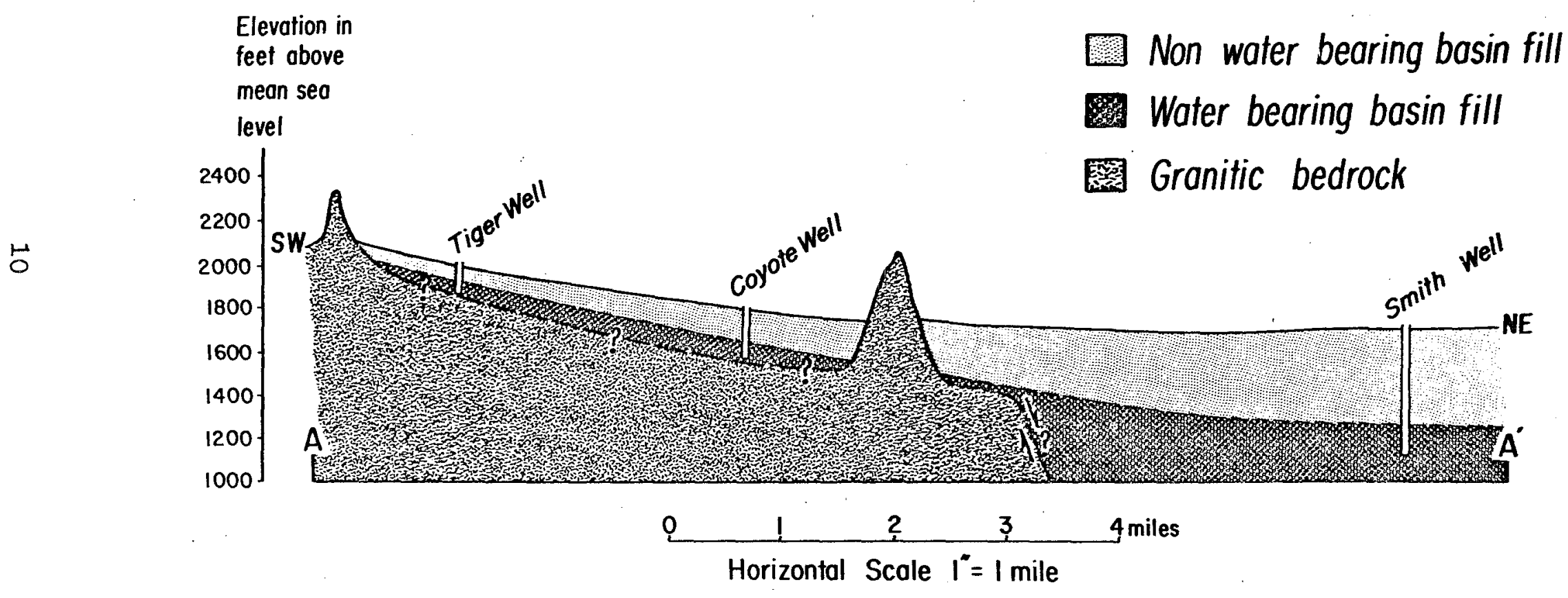

Figure 3. SW-NE cross section (A-A') showing water-bearing and non-water bearing basin fill and inferred Jackrabbit Wash fault. 
groundmass has been destroyed by potassic'alteration, and late-stage propylitic alteration is indicated by small to large clots of chlorite/epidote. Quartz phenocrysts comprise about 17 modal percent of the schist-intruding granite. In contrast, the other granite samples are allotriomorphic granular. Biotite comprises about 2.8 per cent and quartz, 25 to 35 percent of the rock. Epidote is present in trace amounts only. Feldspar is being altered to sericite.

Two inferences can be made from these observations. 1) The granitic rocks represent at least two separate episodes of intrusion and (2) each had a distinct thermal history. With respect to the episodes of intrusion, it is likely that there were more than two events. Zones of highly fractured rock probably surround these plutons and could provide open fracture networks for the storage or circulation of hydrothermal fluids at depth. The distinctive thermal histories suggest that at least some of the fracture channels are sealed by secondary mineralization due to hydrothermal alteration. However, the same hydrothermal alteration could equally well have created an impermeable, shallow cap rock, sealing off a geothermal reservoir at depth.

Northwest of the Belmont Mountains, the rocks are identified as Cretaceous andesite by Wilson and others (1969), but the rock-type identification is at least 
partly in error. Field investigations reveal the occurrence of extensive, northwest-trending ridges of black and gray obsidian and banded rhyolite flows, some of which exceed $75 \mathrm{~m}$ in height. The obsidian frequently exceeds $15 \mathrm{~m}$ in thickness, is phenocryst free, and is very dense and coherent. In places it rests atop the rhyolite flows and forms the ridge top. In other areas the obsidian is interbedded beneath rhyolite flows. The entire sequence dips moderately to the southwest. Additional field work is necessary in this area to determine (1) the source area of the rhyolitic rocks, (2) structural relationships, and (3) whether the sequence represents a series of rhyolitic lava flows, the more likely explanation, or a composite ash flow event in which the obsidian layers represent the densely-welded interiors of individual ash flow cooling units. (A sample of the obsidian is presently being age dated, as a young age, less than about one m.y., would provide a significant heat source for a geothermal resource.)

Structure. Two discrete tectonic orientations are identified in the Vulture Mountains by Rehrig and Heidrick (1976). An older set of strike maxima, measured along an elongate Laramide pluton and associated dikes in the Vulture Mountains, is oriented northeast to east and corresponds with strike maxima, also of Laramide age, determined by the authors for eight-out-of-nine other regions in the Arizona Basin and Range province. A younger set of strike 
maxima are oriented north-northwest, perpendicular to the earlier trend, and are late Tertiary in age. The authors interpret the two tectonic orientations as evidence of former stress fields signifying the following:

"...the Laramide extensional pattern developed under weak, lateral ENE-directed compression combined with differential uplift along multiple NNW to NW-elongate arches, while late Tertiary Basin and Range structures formed under the influence of a non-compressive or tensional stress field which resulted in regional WSW-ENE distension. Preexistent basement anisotrophy is considered a possible influence on both Laramide and late Tertiary structure.

"The opposing regional stress patterns for the two time periods are interpreted as the large-scale effects of plate tectonics. Weak, east-northeastdirected compression was produced by subduction along the Farallon-American plate boundary during the Laramide orogeny ( $50-75$ m.y.B.P.).

"The subsequent release of this lateral compression and attendant inception of Basin and Range tensional stresses occurred upon destruction of the subduction zone about $30 \mathrm{~m} . \mathrm{y} . \mathrm{B} . P .$, and motion spread northwestward as transform faulting occurred along the west edge of the American plate...."

Three distinct structural trends have been identified in the study area. These trends can be seen on the isothermal maps (Figs. 4 and 5), on the Fluoride (Fig. 6) and Mercury (Fig. 7) maps, and on the Aeromagnetic map (Fig. 8). Two of the trends ( $\mathrm{NNW}$ and $\mathrm{NE}$ ) correspond to the Laramide and late-Tertiary Vulture Mountain stress fields of Rehrig and Heidrick (1976). The third structural trend (NW), of unknown age, is also evident from the Landsat lineament map (Lepley, 1978) (Fig. 9) and from air photo interpretation. This northwest trend is especially apparent north of the 


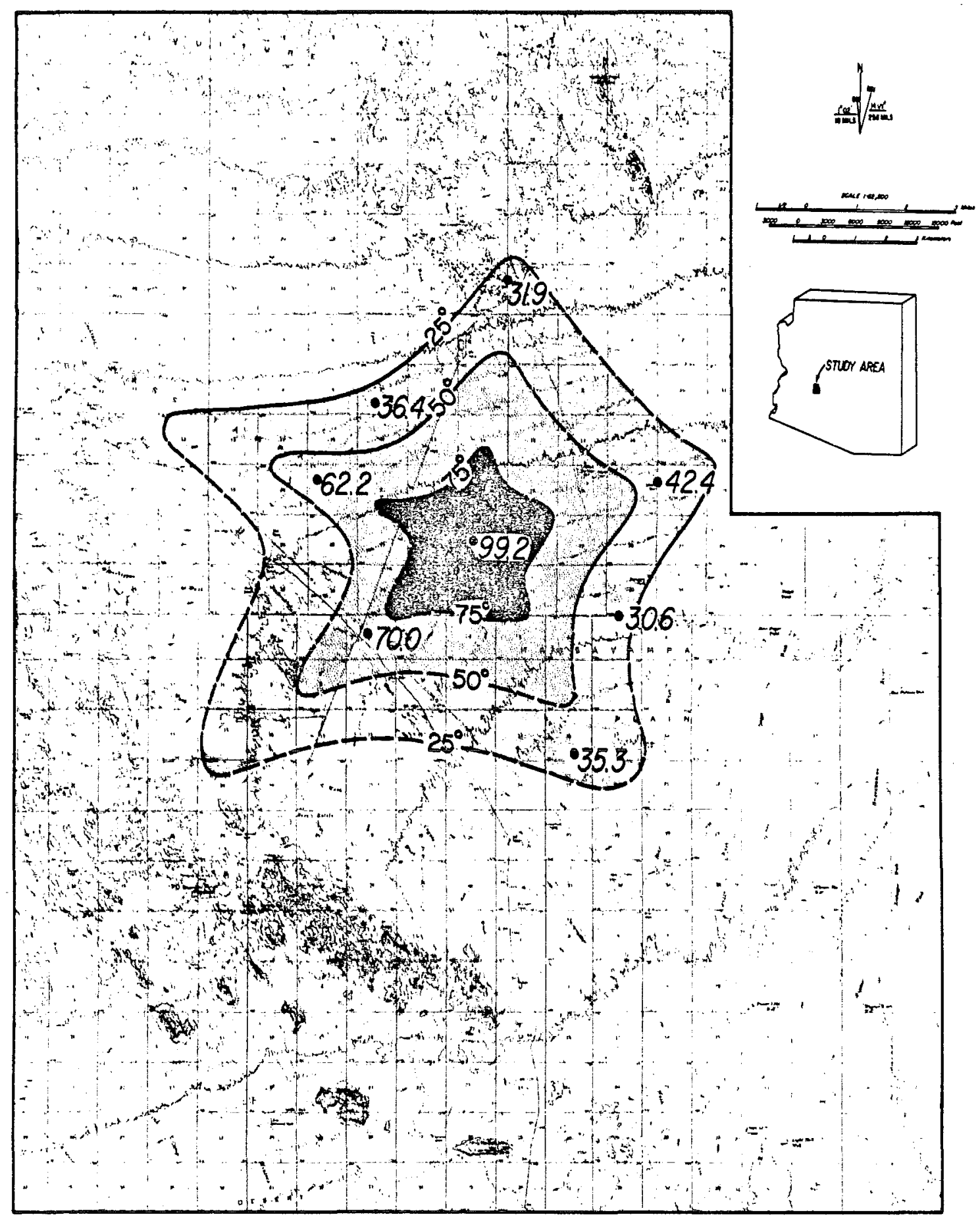

Figure 4. Projected Temperatures $\left({ }^{\circ} \mathrm{C}\right)$ at $500 \mathrm{~m}$ Depth. 


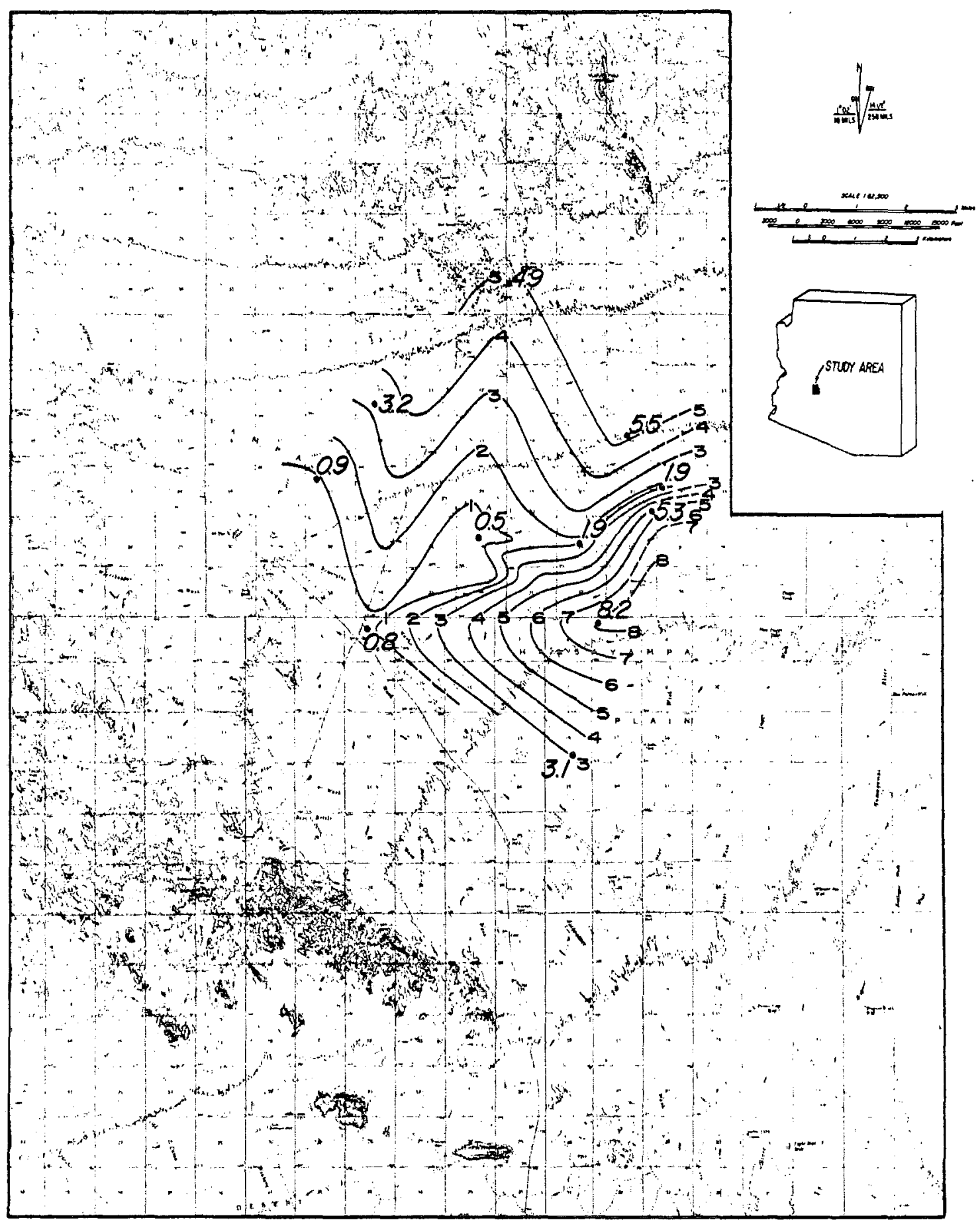

Figure 5. Projected depths in $\mathrm{km}$ to $100^{\circ} \mathrm{C}$ isotherm. 


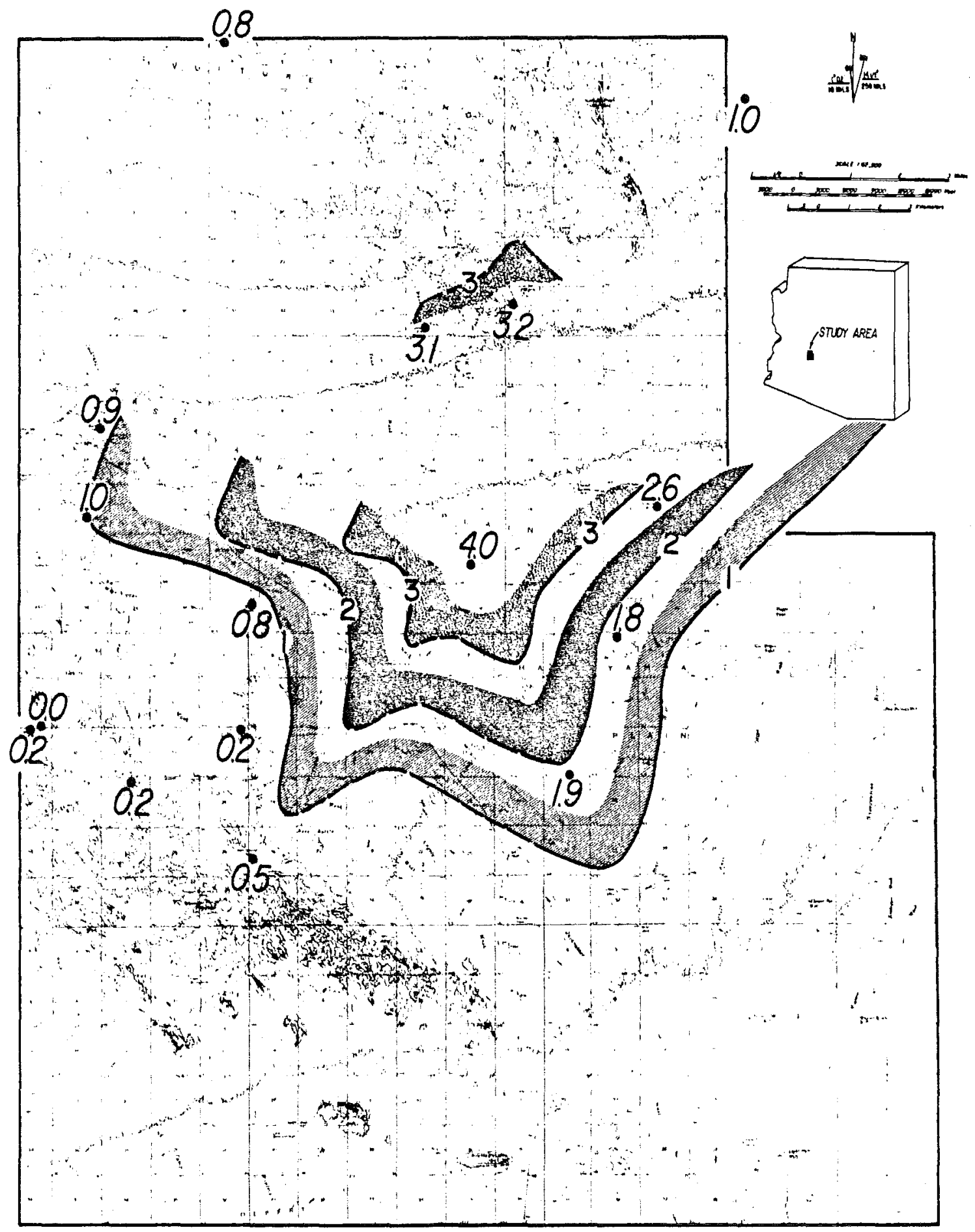

Figure 6. Fluoride Concentrations (M1lligrams Per Liter). Contour interval is one $\mathrm{mg} / \mathrm{l}$. 


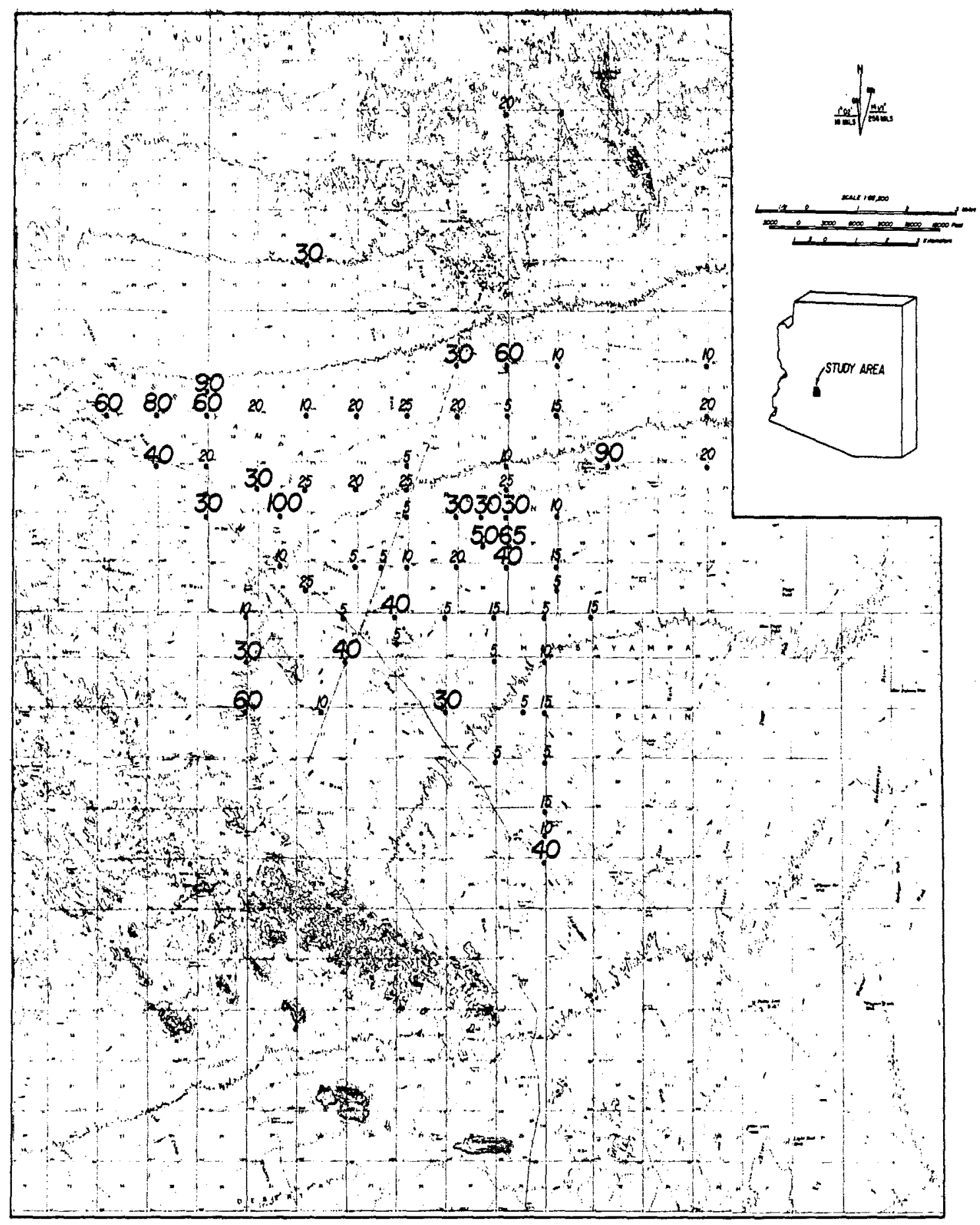

Figure 7. Mercury Concentrations (Parts Per Billion). 


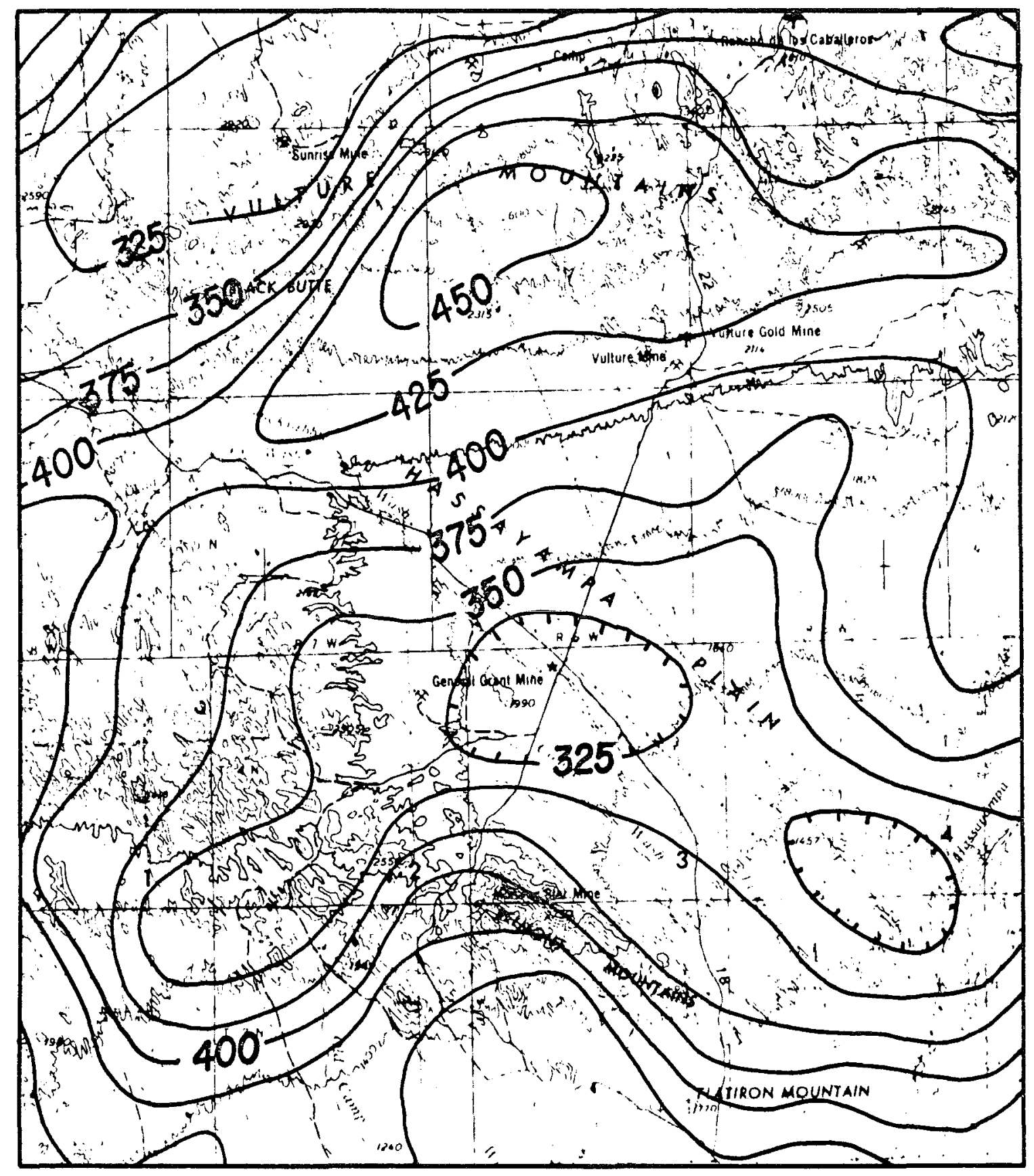

Figure 8. Residual Aeromagnetic Map (From Sauck and Sumner, 1970). Contour interval is 25 Gammas. 


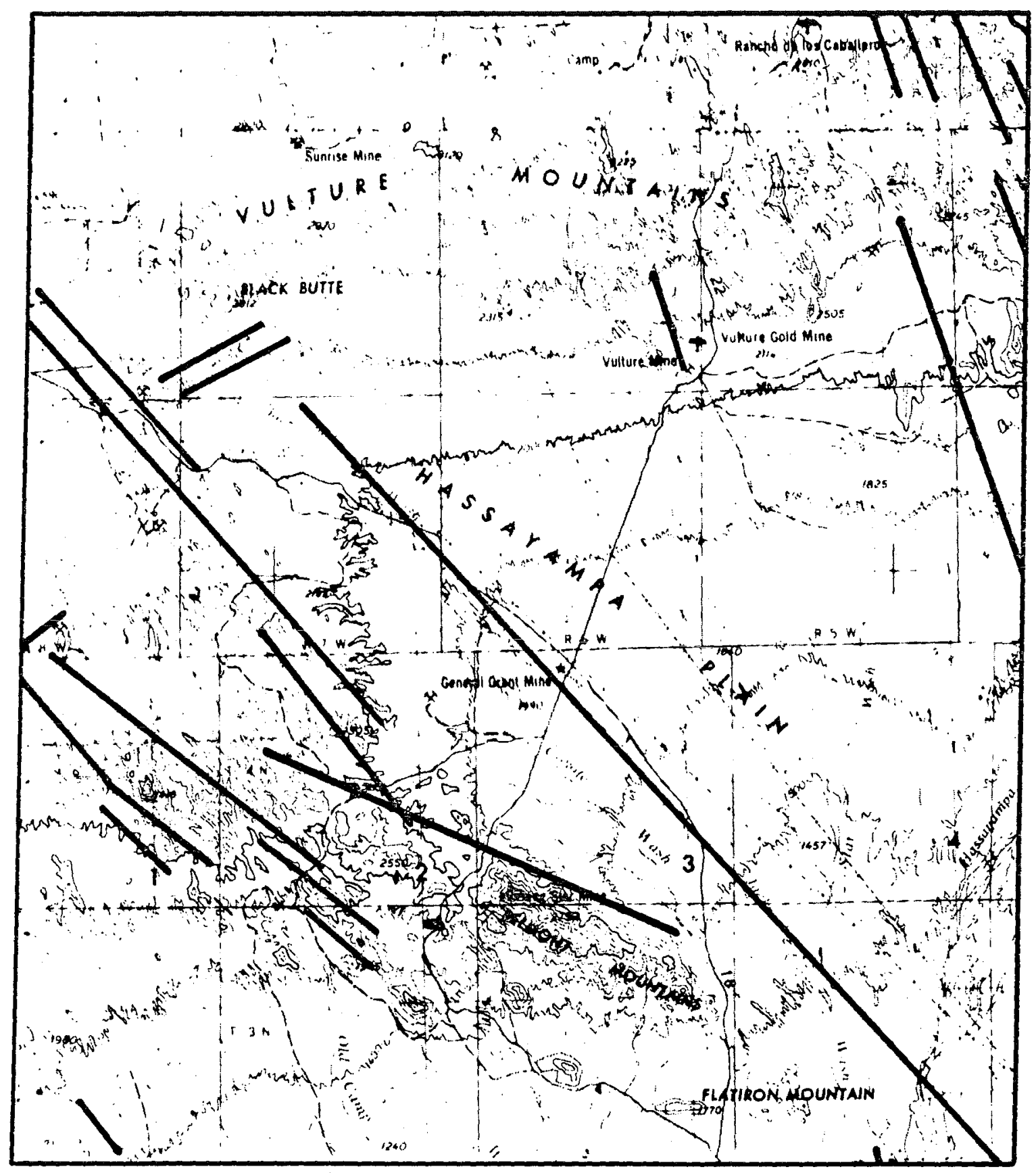

Figure 9. Landsat Lineaments (From Lepley, 1978). 
Belmont Mountains where Jackrabbit Wash trends southeastward along the trace of a prominent northwest-directed Landsat lineament. In addition numerous northwest-trending lineaments occur in the eastern Vulture Mountains. A single, shorter lineament strikes northwest through the Vulture Mine area and probably is the trace of the Talmage Fault (Hutchinson, 1921). The correlation of present-day structural trends with Laramide and late-Tertiary trends indicates that these features have been extant for many millions of years; that the channelways still may be open and may provide conduits for fluids moving through or up from the deep subsurface. The intersection of these tectonic features may be the source of local upwellings of warm water.

\section{GEOPHYSICS:}

Aeromagnetics. The Residual Aeromagnetic Map of Arizona (Sauck and Sumner, 1970) (Fig. 8) shows two closed magnetic lows in the northern Hassayampa Plain, one centered on Jackrabbit Wash, the other several miles to the southeast. A second, less prominent feature is a northeast-trending trough of low magnetism, only slightly higher than the two closed magnetic lows, which crosses north of the Belmont Mountains, crosses the more northerly magnetic low and the Hassayampa Plain, and dies out west of the Hassayampa River. The magnetic trough nearly coincides with the proposed northeast-trending fault (Fig. 2), and one closed magnetic low occurs at the intersection of this fault and the 
northwest-trending Jackrabbit Wash fault. The amplitude of the magnetic features is low and their significance is uncertain. One explanation for the observed features is the upwelling of hot water along the fault or at the fault intersection, with attendant hydrothermal alteration of magnetite to pyrite which would create a magnetic low.

Gravity. Gravity data in the northern Hassayampa Plain are scarce so that any attempt at interpretation is difficult. From the data available, little in the way of structural features is apparent (Fig. 10). Most likely the Hassayampa Plain comprises a relatively thin cover of mountain-derived sediments overlying a bedrock basement the depth to which varies locally. A bedrock high, evident from isolated schist outcrops, extends south from the Vulture Mountains nearly to Indian Buttes (Fig. 2), but it is not known whether this feature is due to local basement relief or to faulting.

Thermal Gradients: Thermal gradients were measured in eight wells, and Birdwell temperature logs were provided by Fugro, Inc. for three additional test holes in the study area (Fig. 11). The data are listed in Table 1. Most of the temperature gradients are normal for the Basin and Range province, indicative of recharge to the regional aquifer. The three highest gradients, wells A, B, and C (Fig. 11), which are exceptions, are spacially closest to the fault intersection. Possible explanations for the high gradients 


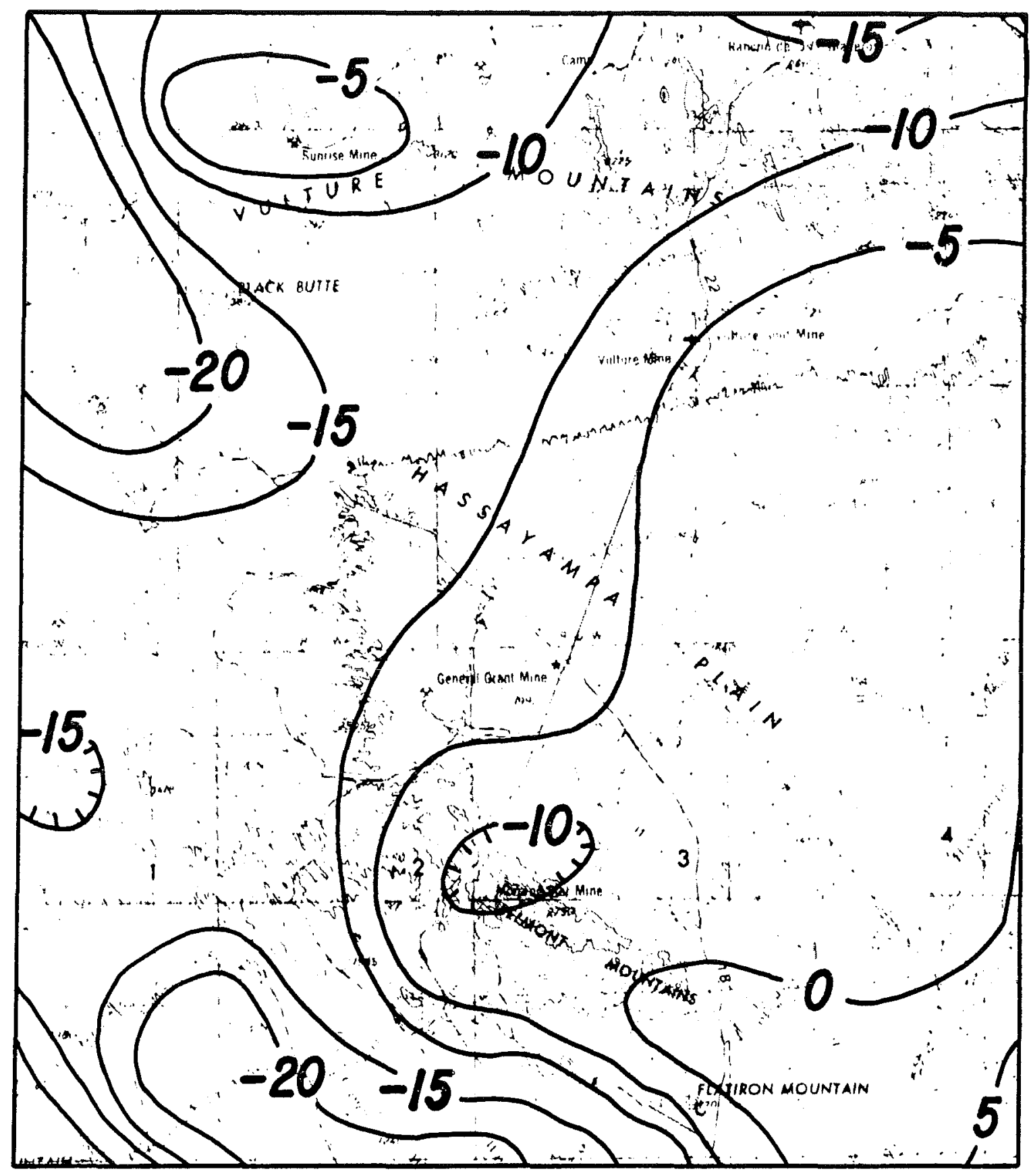

Figure 10. Terrain Corrected Residual Bouguer Gravity Map (From Lysonski and Sumner, 1979, Unpublished Data). Contour interval is 5 Milligals. 


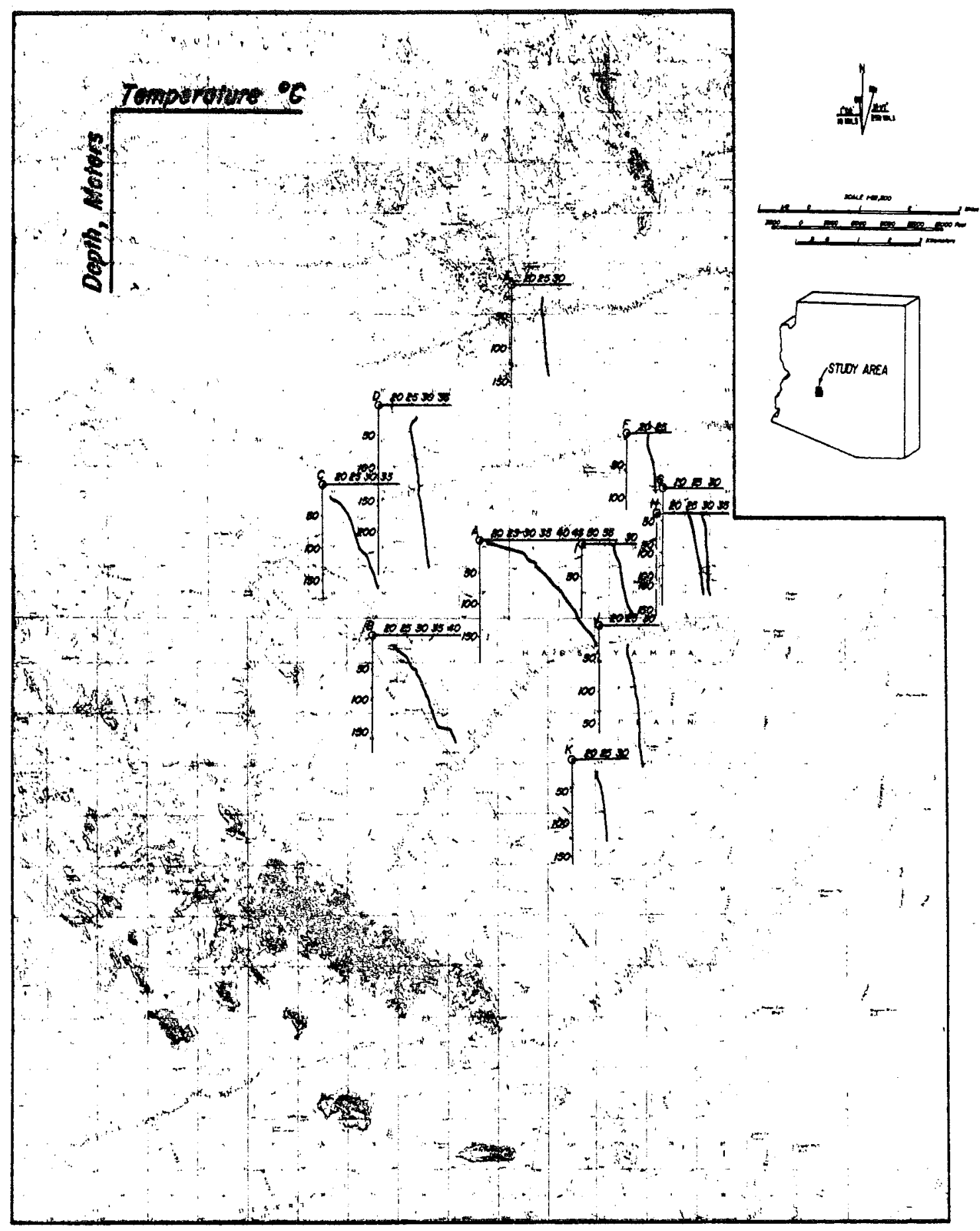

Figure 11. Measured Geothermal Gradients $\left({ }^{\circ} \mathrm{C} / \mathrm{km}\right)$. Circles indicate well locations. 
Table 1. Measured Geothermal Gradients, Northern Hassayampa plain, Arizona

Well

No.

A

$\mathrm{B}$

C

D

E

F

G

$\mathrm{H}$

I

$J$

K
Township and Range

Location

(Gila-Salt Meridian)

$5 \mathrm{~N}-6 \mathrm{~W}-25 \mathrm{SE} N \mathrm{NW}$

$4 N-6 W-4 \cdot N E N E$

$5 N-6 W-21 N W$

$5 N-6 W-10$ SE SW

$6 N-5 W-31$ SW NW

$5 N-5 W-16$ SE NW

$5 N-5 W-22 \quad S W \quad N E$

$5 N-5 W-21$ SE SE

$5 N-5 W-29$ SE NW

$4 N-5 W-5 N W \quad N E$

$4 N-5 W-18$ SW SE

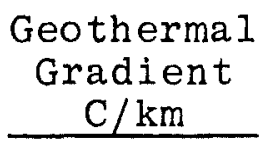

140.1

94.8

87.5

23.2

15.6

18.3

41.4

19.0

51.8

9.0

24.8 
include: (I) shallow convective circulation of warm water,

(2) refraction of heat across a range-bounding fault, and

(3) rise of warm water along a range-bounding fault.

(1) High thermal gradients measured at relatively shallow depths may result from shallow convective circulation of warm water (Batzle and Simmons, 1977). However, shallow convective circulation seems an unlikely explanation in the study area because of the widespread occurrence of normal gradients. Additional zones of warm-water discharge should be randomly located throughout the area, and these are not observed. In addition the ground-water gradient points to the steady flow of ground water to the southeast, rather than to convective circulation.

(2) In a non-geothermal area, upwarping of isotherms and a small heat flow anomaly may result from refraction of heat, caused by the thermal conductivity contrast across a range-bounding fault (Blackwell and Chapman, 1977). This is a more plausible explanation of the observed gradients, but still is not entirely satisfactory. Gradients B and C (Fig. 11) are located along the range-bounding fault, but so is gradient $\mathrm{K}$ which, according to this explanation, might reasonably be expected to be much higher.

(3) The most plausible explanation for the observed gradients seems to be the rise of hot water along the rangebounding fault (Blackwell and Chapman, 1977; Chapman and other, 1978; Hahman, in press) and at the fault intersection. 
Surface water percolates down through faults, fractures, and permeable beds where it is heated by temperatures that normally increase with depth. The water may or may not be stored in a reservoir for some period of time. Difference in piezometric head between recharge and discharge zones, and the reduced density of warm water eventually force the thermal waters toward the surface through a fault zone. Hot springs may or may not occur along the range front to signal this phenomenon. Where hot springs are absent, leakage of thermal waters into the alluvium can be significant. Fault intersections, leaking greater volumes of hydrothermal water into the surrounding rock and alluvium, could be expected to cause extensive hydrothermal alteration. As stated above, such alternation of magnetite to pyrite could easily account for the two closed magnetic lows observed in the study area, one of which occurs over the fault intersection. 


\section{GEOCHEM ISTRY}

Water. Nine chemical analyses of water samples from the study area, Group I, and eight analyses of samples from Wickenburg, Group II, are presented in Table 2. Cation ratios, chemical geothermometers and measured temperatures are presented in Table 3. Sample locations are shown in Figure 12. The data are used to provide a chemical characterization of the waters and to estimate aquifer temperatures at depth.

For comparison of the Group I and Group II samples, the major ions of 13 samples, for which complete analyses are available, are plotted on a Piper diagram (Piper, 1944) (Fig. 13). Two distinct chemical trends representing the Hassayampa and Wickenburg samples, and three anomalous analyses, can be identified on the diagram. Most Group I samples (nos. 2, 3, 8 and 9) are characterized by sodium, bicarbonate water, whereas all Group II samples (nos. II, 12, 13, 14 and 17) and sample 7 from Group I are characterized by sodium, calcium, bicarbonate water. Samples 5, 6 and 10 are each distinct in chemical composition, and represent waters from separate sources or waters of mixed origin.

Anomalous concentrations of certain elemental constituents and anomalous elemental ratios in water and soil samples can be inferred to indicate qualitatively a hightemperature system that has no surface expression of 
TABLE 2. CHEMICAL ANALYSES OF WATER FROM SFLECTED WELLS IN THE WICKENBURG AND NORTHERN HASSAYAMPA AREA, ARIZONA

(Chemical constituents in milligrams per 1iter)

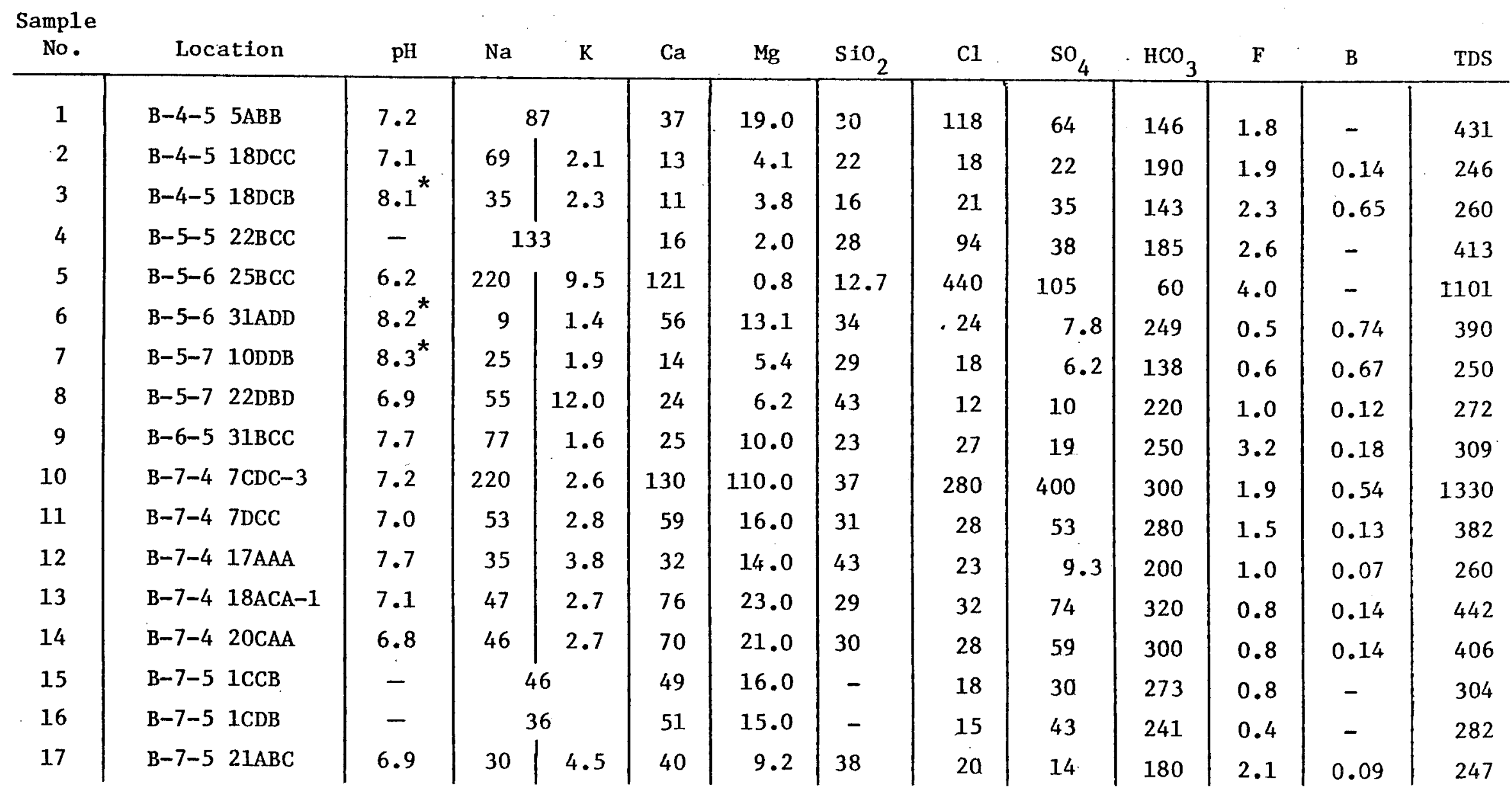

* Laboratory measurement 
TABLE 3:

$\mathrm{T}_{1}=$ Silica temperatures assuming quartz equilibrium and conductive cooling.

$\mathrm{T}_{2}=$ Silica temperatures assuming equilibrium with $\alpha$-cristobalite

$\mathrm{T}_{3}=$ Silica temperatures assuming equilibrium with chalcedony.

$\mathrm{T}_{4}=\mathrm{Na}-\mathrm{K}-\mathrm{Ca}$ temperatures. 


\section{TABLE 3:}

$\begin{aligned} \mathrm{T}_{1}= & \text { Silica temperatures assuming quartz equilibrium } \\ & \text { and conductive cooling. }\end{aligned}$

$\mathrm{T}_{2}=$ Silica temperatures assuming equilibrium with $\alpha$-cristobalite.

$\mathrm{T}_{3}=$ Silica temperatures assuming equilibrium with chalcedony.

$\mathrm{T}_{4}=\mathrm{Na}-\mathrm{K}-\mathrm{Ca}$ temperatures. 
TABLE 3. RATIOS OF SELECTED CHEMICAL CONSTITUENTS AND ESTIMATED AQUIFER TEMPERATURES (Chemical constituents in milligrams per 1iter. Chemical geothermometers in ${ }^{C}$.)

\begin{tabular}{|c|c|c|c|c|c|c|c|c|c|c|}
\hline $\begin{array}{l}\text { Sample } \\
\text { No.* }\end{array}$ & Temperature ${ }^{\circ} \mathrm{C}$ & $\mathrm{C} 1 / \mathrm{F}$ & $\mathrm{C} 1 / \mathrm{B}$ & $\mathrm{Cl} / \mathrm{SO}_{4}$ & $\mathrm{Mg} / \mathrm{Ca}$ & $\mathrm{Mg} / \mathrm{Cl}$ & $\mathrm{T}_{1}$ & $\mathrm{~T}_{2}$ & $\mathrm{~T}_{3}$ & $\mathrm{~T}_{4}$ \\
\hline 1 & 28.5 & 65.6 & - & 0.81 & 0.51 & 0.61 & 79.4 & 48.1 & 29.6 & - \\
\hline 2 & 25.0 & 9.5 & 128.6 & 0.10 & 0.32 & 0.23 & 67.1 & 35.1 & 17.8 & 54.4 \\
\hline 3 & - & 9.1 & 32.3 & 0.15 & 0.35 & 0.18 & 55.3 & 22.9 & 6.5 & 53.7 \\
\hline 4 & 25.5 & 36.2 & - & 0.51 & 0.13 & 0.02 & 76.6 & 45.1 & 26.9 & - \\
\hline 5 & 51.0 & 110.0 & - & 7.33 & 0.01 & 0.002 & 47.2 & 14.6 & - & 66.4 \\
\hline 6 & 31.0 & 48.0 & 32.4 & 0.10 & 0.23 & 0.55 & 84.6 & 53.6 & 34.7 & 5.0 \\
\hline 7 & 34.0 & 30.0 & 26.9 & 0.13 & 0.39 & 0.30 & 78.0 & 46.6 & 28.3 & 41.2 \\
\hline 8 & 25.5 & 12.0 & 100.0 & 0.06 & 0.26 & 0.52 & 94.9 & 64.5 & 44.7 & $73.3^{\star}$ \\
\hline 9 & 28.5 & 8.4 & 150.0 & 0.11 & 0.40 & 0.37 & 68.8 & 36.9 & 19.4 & 36.4 \\
\hline 10 & 22.5 & 147.4 & 518.5 & 0.93 & 0.85 & 0.39 & 88.3 & 57.4 & 38.2 & 29.9 \\
\hline 11 & 22.0 & 18.7 & 215.4 & 0.10 & 0.27 & 0.57 & 80.8 & 49.5 & 30.1 & 34.2 \\
\hline 12 & 27.5 & 23.0 & 328.6 & 0.12 & 0.44 & 0.61 & 94.9 & 64.5 & 44.7 & 48.0 \\
\hline 13 & 23.5 & 40.0 & 228.6 & 0.10 & 0.30 & 0.72 & 78.0 & 46.6 & 28.3 & 27.1 \\
\hline 14 & 21.0 & 35.0 & 200.0 & 0.09 & 0.30 & 0.75 & 79.4 & 48.1 & 29.6 & 28.2 \\
\hline 15 & - & 22.5 & - & 0.07 & 0.33 & 0.89 & - & - & - & - \\
\hline 16 & - & 37.5 & - & 0.06 & 0.29 & 1.00 & - & - & - & - \\
\hline 17 & 26.0 & 9.5 & 222.2 & 0.11 & & 0.46 & 58.7 & 58.7 & 39.3 & 47.1 \\
\hline
\end{tabular}

${ }_{* *}^{*}$ See Table 2 for locations.

A Mg correction applied to sample 8 yields this value. other samples did not require a Mg correction. 


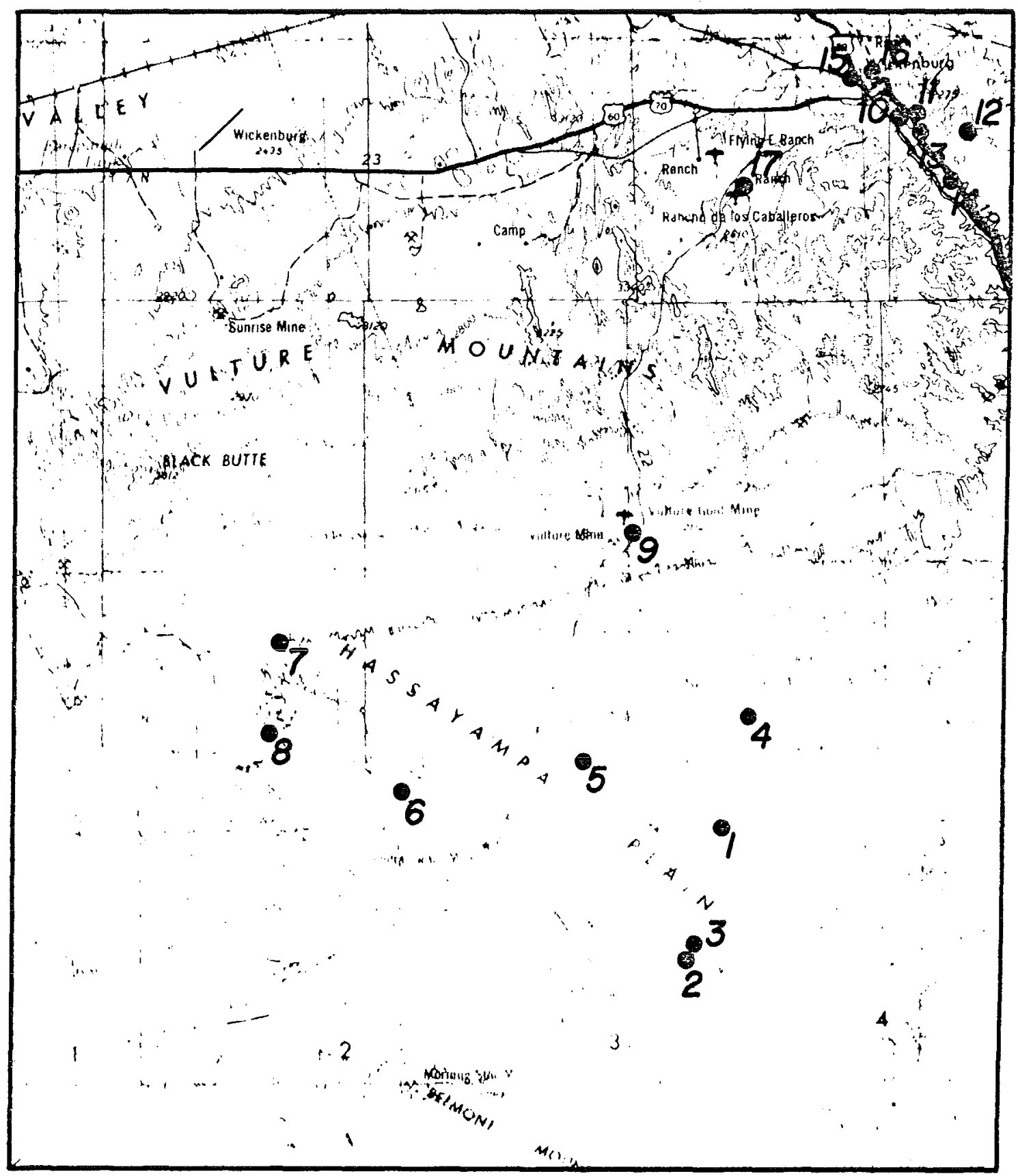

Figure 12. Locations of Water Samples. 


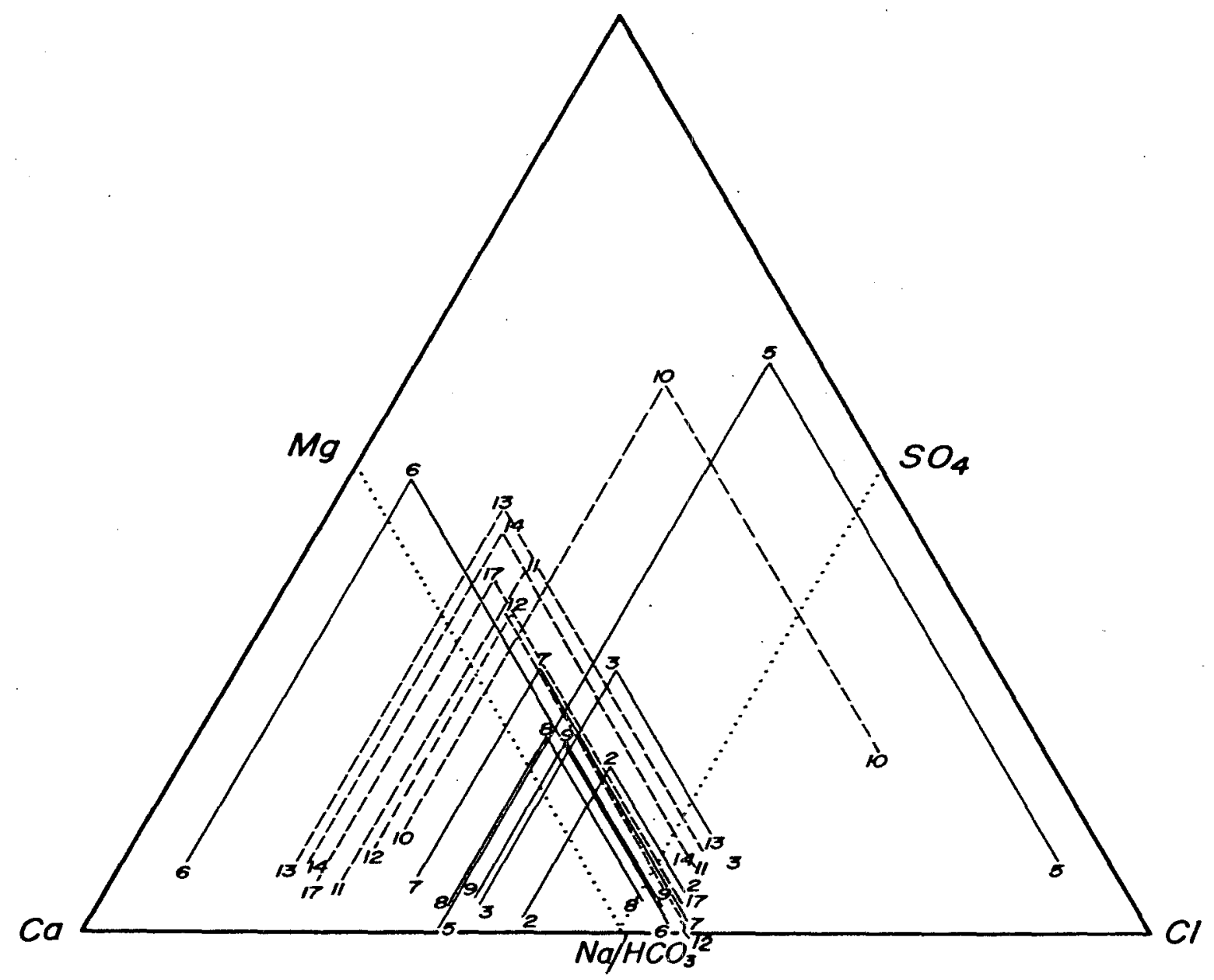

Figure 13. Piper Diagram showing chemical distinction between Group I (Hassayampa) water samples (solid lines) and Group II (Wickenburg) water samples (dashed lines). 
thermal water. Mahon (1970) showed that high Cl/F and $\mathrm{Cl} / \mathrm{SO}_{4}$ ratios in a geothermal area generally indicate high temperature in the system. Sample 5 has high values for both ratios; sample 10 has a high $\mathrm{Cl} / \mathrm{F}$ ratio (Table 3 ). The $C l / B$ and $C l / F$ ratios for Group II samples (except sample 10) are very similar, supporting the inference that those waters are from the same aquifer and are distinct from Group I samples. The same inference with respect to source cannot be made from the Group $\mathrm{I} \mathrm{Cl/F}$ and $\mathrm{Cl} / \mathrm{B}$ ratios, as the Group I Cl/F ratios vary among samples by a factor greater than 7.5 and the $C l / B$ ratios vary by a factor of 6 . Hydrothermal alteration commonly results in uptake of magnesium by the wall rock in the manufacture of Mg-chlorite and $\mathrm{Mg}$-montmorillonite, with resultant depletion of magnesium in the thermal water. Consequently low $\mathrm{Mg} / \mathrm{Ca}$ and $\mathrm{Mg} / \mathrm{Cl}$ ratios also may reflect thermal water. Sample 5 shows ratios of $\mathrm{Mg} / \mathrm{Ca}$ and $\mathrm{Mg} / \mathrm{Cl}$ lower than all other samples by two orders of magnitude. These qualitative indicators strongly suggest a thermal origin for sample 5 .

Chemical geothermometers, based on the temperature dependence to certain elemental concentrations in thermal water, are used to estimate reservoir temperatures at depth. However, certain assumptions must be made in applying the geothermometers (White, 1970): I) the chemical reactions controlling the amount of a chemical constituent taken into solution by hot water are temperature dependent, 2) an adequate supply of these chemical constituents is present 
in the aquifer, 3) chemical equilibrium has been established between the hot water and the wall rocks which supply the chemical constituents, 4) hot water from the aquifer flows rapidly to the surface, and 5 ) the chemical composition of the hot water does not change (mix with cold water, evolve gas, or precipitate minerals) as it rises to the surface. Often these assumptions cannot be demonstrated in a field situation, so that chemical geothermometers must be used with caution. With that understanding, chemical geothermometers can provide a useful reconnaissance tool for making a preliminary estimate of reservoir temperatures at depth. There is excellent correlation between the silica and $\mathrm{Na}-\mathrm{K}-\mathrm{Ca}$ predicted aquifer temperatures for the Group II samples (Table 3 ), the best agreement occurring between $\mathrm{Na}-\mathrm{K}-\mathrm{Ca}$ and $\alpha$-cristobalite, rather than with chalcedony as is commonly found with most Arizona Basin and Range water samples. This would be a result of host rock mineralogic composition. There is an equally good correlation of chemical geothermometers among the individual water samples from Group II. The Group II samples predict an aquifer temperature of about $35^{\circ} \mathrm{C}$ in the Wickenburg area. (Mean $\mathrm{T}\left(\mathrm{SiO}_{2}\right.$ ) is $35.0^{\circ} \mathrm{C}$; mean $\mathrm{T}(\mathrm{Na}-\mathrm{K}-\mathrm{Ca})$ is $\left.35.7^{\circ} \mathrm{C}.\right)$

Among Group I samples correlation is less distinct. For samples 7,8 , and $9, \mathrm{Na}-\mathrm{K}-\mathrm{Ca}$ agrees well with chalcedony and predicts subsurface temperatures up to $73^{\circ} \mathrm{C}$. $\mathrm{Na}-\mathrm{K}-\mathrm{Ca}$ of samples 2 and 3 correlates with conductive quartz and 
predicts a maximum subsurface temperature of $67^{\circ} \mathrm{C}$. For sample 5, the silica geothermometer is lower than the measured temperature which might be explained in several ways: (1) the analysis could be in error, (2) some precipitation of silica could have occurred, lowering the silica concentration in the water, or (3) the thermal water could be slightly mixed with cold water, also lowering the silica concentration. If this last explanation is correct, it would lend support to the suggestion that all waters in the study area are of mixed origin; that is, thermal water from depth is mixing to various degrees with shallow cold water. The chemical geothermometers are therefore predicting lower subsurface temperatures than actually exist. Mixing model calculations will resolve this problem when sufficient data are available. An interesting feature of the water chemistry is the apparent distinction among the Group I samples which may be related to structural control. Samples $6,7,8$, and 9 were collected northwest of the northeast-trending fault (Figs. 2 and 12), and samples 2 and 3 were collected southeast of the fault. Samples 5 and 6 , which yield anomalous chemical analyses, originate nearest the fault intersection. Furthermore, the lowest predicted temperature, $36.9^{\circ} \mathrm{C}$, is from sample 9, which is located farthest from the fault intersection (Fig. 11).

Soil. Soil samples were collected at section and quarter-section corners over $150 \mathrm{~km}^{2}$ for mercury analysis. 
Mean value of $\mathrm{Hg}$ for the sampled area is 25 parts per billion $(\mathrm{ppb})$. Values greater than $25 \mathrm{ppb}$ are distinguished in Figure 7 by larger numerals. Three trends, closely following the structural trends outlined by the other surveys, are apparent. The higher Hg values imply leakage of mercury along the faults. However, mercury anomalies often mark fossil (now cold) thermal systems and consequently, they too must be viewed with caution.

\section{SUMMARY AND CONCLUSIONS}

The northern Hassayampa Plain is a broad, sedimentfilled basin with a complexly faulted basement. Depth to bedrock depends upon the degree of rotation and displacement of basement blocks and probably ranges from shallow to many hundreds of meters.

The three distinct structural trends (NE, NNW, and NW) identified from air photo interpretation, Landsat lineaments, and geochemical trends are here interpreted as fault traces. Two of these inferred faults (NE and NNW) agree with the strike maxima identified in the Vulture Mountains by Rehrig and Heidrick (1976).

The measured geothermal gradients define a single discrete area of hydrologic discharge that is about $30 \mathrm{~km}^{2}$ and can best be explained as being fault controlled. The three wells that constrain the area are adjacent to one another and are the wells located nearest the faults and the fault intersection. The maximum reported water temperature in the study area, $53^{\circ} \mathrm{C}$, is from well A (Fig. 11) which yields 
an anomalous chemical analysis, sample 5, and has the highest geothermal gradient, $140^{\circ} \mathrm{C} / \mathrm{km}$. It seems likely that the water in this well is rising from a deep thermal source along fault planes and fractures. The origin of other waters is uncertain, but may represent waters from the same source, mixed to a greater degree with cold water. The maximum temperature of $73^{\circ} \mathrm{C}$ predicted by geochemical methods probably represents a minimum subsurface temperature and is too low as a result of not satisfying the necessary assumptions. Mixing of hot water rising from the deep subsurface, with water in a shallow, cold aquifer, can distort measured temperatures, chemical geothermometers, and geothermal gradients. Although a reliable estimate of the geothermal potential of the northern Hassayampa Plain cannot be made because of insufficient data, certain trends have been identified that strongly suggest the presence of a geothermal resource that is primarily controlled by intersection of the principal zones of faulting. Maximum temperature and reservoir volume cannot be predicted without detailed geologic and geophysical surveys, and deep drilling. Recommendations are made for additional field investigations, in order of priority, which should substantially assist in evaluating this geothermal anomaly. 
RECOMMENDATIONS

1. Detailed geologic mapping of the Belmont Mountains and the area to the northwest thereof, with rock chemical analyses and age dates as necessary, to understand the geologic setting of the geothermal reservoir.

2. Detailed gravity survey over the inferred faults and fault intersection, to determine subsurface structures and depths to bedrock.

3. Shallow drill holes $(50 \mathrm{~m}$ ) across the faults and the fault intersection, to determine possible zones of high heat flow.

4. Electrical resistivity survey, to identify zones of and depths to thermal waters in the deep subsurface.

5. Exhaustive water sampling with complete chemical and isotopic analyses, to identify and characterize the deep and shallow aquifers, and to provide enough samples to determine if mixing of hot and cold waters is occurring. Mixing model calculation will more accurately determine subsurface temperature. 


\section{BIBLIOGRAPHY}

Batzle, M. L. and Simmons, G., 1977, Assessing geothermal areas during drilling. Geothermal Resources Council, Transactions, Vol. 1, p. 13-15.

Blackwel1, D. D., and Chapman, D. S., 1977, Interpretation of geothermal gradient and heat flow data for Basin and Range geothermal systems. Geothermal Resources Council, Transactions, Vol. 1, p. 19-20.

Chapman, D. S., Kilty, K. T., and Mase, C. W., 1979, Temperatures and their dependence on groundwater flow in shallow geothermal systems. Geothermal Resources Council, Transactions, Vol. 2, p. 79-81.

FUGRO, 1979, Personal communication.

Hahman, W. R., Sr., 1979, Geothermal energy in Arizona. Geothermal Energy, in press.

Hutchinson, W. S., 1921, The Vulture Mine. Engineering and Mining Journal, Vol. III, No. 7, p. 298-302.

Lepley, L. K., 1978, Landsat lineament map of Arizona with emphasis on Quaternary features. in Low Temperature Geothermal Reservoir Site Evaluation in Arizona, Quarterly Progress Report for Period February 1, 1978April 30, 1978. Bureau of Geology and Mineral Technology, Tucson, Arizona, p. 63-91.

Lysonski, J. and Sumner, J. S., 1979, Terraine Corrected Residual Bouguer Gravity Map of Arizona, unpublished data.

Mahon, W. A. J., 1970, Chemistry in the exploration and exploitation of hydrothermal systems. in Proceedings United Nations Symp. on the Development and Utilization of Geothermal Energy: Pisa, Vol. 2, Part 2, Geothermics, Spec. Issue 2, p. 1310-1322.

NOAA, 1973, Monthly normals of temperature, precipitation and heating and cooling degree days 1941-1970. National Climatic Center, Asheville, N. C.

Piper, A. M., 1944, A graphic procedure in the geochemical interpretation of water analyses. Transactions, American Geophysical Union, Papers in Hydrology, p. 914-923. 
Rehrig, W. A., Shafiqullah, M., and Damon, P. E., 1979, Geochronology and geology of the Vulture Mountains, Maricopa County, Arizona. Arizona Geological Society Digest, Vol. 12, in press.

Rehrig, W. A. and Heidrick, T. L., 1976, Regional tectonic stress during Laramide and late Tertiary intrusive periods, Basin and Range province, Arizona. Arizona Geological Society Digest, Vol. 10, p. 205-228.

Sauck, W. A. and Sumner, J. S., 1970, Residual Aeromagnetic Map of Arizona. Department of Geosciences, University of Arizona, Tucson, Arizona, 1:1,000,000 scale.

White, D. E., 1970, Geochemistry applied to the discovery, evaluation, and exploitation of geothermal energy resources. in Proceedings United Nations Symp. on the Development and Utilization of Geothermal Energy: Pisa, Vol. 1, Part 2, Geothermics, Spec. Issue 2, p. 58-80.

Wilson, Moore, and Cooper, 1969, Geologic Map of Arizona. 